Article

\title{
Environmentally Friendly Utilization of Wheat Straw Ash in Cement-Based Composites
}

\author{
Shazim Ali Memon ${ }^{1, *}$, Israr Wahid ${ }^{2}$, Muhammad Khizar Khan ${ }^{2}$, Muhammad Ashraf Tanoli ${ }^{3}$ \\ and Madina Bimaganbetova ${ }^{1}$ \\ 1 Department of Civil Engineering, School of Engineering, Nazarbayev University, \\ Astana 010000, Republic of Kazakhstan; madina.ismagulova@nu.edu.kz \\ 2 Department of Civil Engineering, COMSATS Institute of Information Technology, \\ Abbottabad 22060, Pakistan; asrar.wahid@gmail.com (I.W.); mkhizar@ciit.net.pk (M.K.K.) \\ 3 Department of Civil Engineering, GIK Institute of Engineering Sciences and Technology, \\ Topi 23640, Pakistan; matanoli@giki.edu.pk \\ * Correspondence: shazim.memon@nu.edu.kz; Tel.: +7-778-443-8516
}

Received: 15 March 2018; Accepted: 6 April 2018; Published: 25 April 2018

\begin{abstract}
The open burning of biomass residue constitutes a major portion of biomass burning and leads to air pollution, smog, and health hazards. Various alternatives have been suggested for open burning of crop residue; however, each of them has few inherent drawbacks. This research suggests an alternative method to dispose wheat straw, i.e., to calcine it in a controlled environment and use the resulting ash as a replacement of cement by some percentage in cement-based composites. When wheat straw, an agricultural product, is burned, it is very rich in $\mathrm{SiO}_{2}$, which has a pozzolanic character. However, the pozzolanic character is sensitive to calcination temperature and grinding conditions. According to the authors' best knowledge, until now, no systematic study has been devised to assess the most favorable conditions of burning and grinding for pozzolanic activity of wheat straw ash (WSA). Hence, a systematic experimental program was designed. In Phase I, calcination of WS was carried out at $500^{\circ} \mathrm{C}, 600^{\circ} \mathrm{C}, 700{ }^{\circ} \mathrm{C}$, and $800^{\circ} \mathrm{C}$ for $2 \mathrm{~h}$. The resulting ashes were tested for color change, weight loss, XRD, XRF, Chapelle activity, Fratini, and pozzolanic activity index (PAI) tests. From test results, it was found that beyond $600{ }^{\circ} \mathrm{C}$, the amorphous silica transformed into crystalline silica. The WSA calcined at $600{ }^{\circ} \mathrm{C}$ was found to satisfy Chapelle and Fratini tests requirements, as well as the PAI requirement of ASTM at 28 days. Therefore, WSA produced at $600{ }^{\circ} \mathrm{C}$ (WSA600) showed the best pozzolanic performance. In Phase II, WSA600 was ground for various intervals (15-240 min). These ground ashes were tested for SEM, Blaine fineness, Chapelle activity, Fratini, and PAI tests. From test results, it was observed that after 120 min of grinding, there was an increase of $48 \%$ in Blaine surface area, with a consequence that WSA-replaced cement cubes achieved a compressive strength almost similar to that of the control mix. Conclusively, wheat straw calcined at $600{ }^{\circ} \mathrm{C}$ and ground for $120 \mathrm{~min}$ was found to be the most effective way to use pozzolanic material in cement-based composites. The addition of WSA in cement-based composites would achieve manifold objectives, i.e., aiding in the production of environmentally friendly concrete, the use of wheat straw as fuel for electricity production, and adding economic value to wheat straw.
\end{abstract}

Keywords: wheat straw ash; pozzolanic activity; cement; concrete; calcination; grinding; environmental friendly materials

\section{Introduction}

The burning of biomass is a huge environmental concern, especially in agricultural countries. This leads to deteriorated air quality, haze conditions, and serious repercussions on the health of 
humans [1,2]. Biomass burning leads to emissions of carbonaceous aerosol pollutants and a number of trace gases such as CO, VOCs, and NOX, which may lead to photochemical smog [3]. A few of the main components of biomass burning are grassland fires, open-field burning of agricultural leftover material, i.e., crop residue, temperate and boreal forest fires, domestic biofuel combustion [4], and residential wood combustion [5]. However, in countries with large-scale agricultural production like China and India, open-field burning of crop residue is a significant portion of biomass emission [6]. Traditionally, crop residues were used for a number of reasons, but with the advancement of agricultural technologies, burning of crop residue (Figure 1) became the most viable option for farmers [7]. Crop residue burning is done in order to prepare the field for the next cycle of cultivation or to control pests and weeds [8]. In one research, the authors concluded that out of $750 \mathrm{Tg}$ of biomass burned in Asia, $250 \mathrm{Tg}$ (33.4\%) was comprised of open-field burning. Out of this, the major contributors were India $84 \mathrm{Tg}$ and China $10 \mathrm{Tg}$ [9]. In addition, another important aspect of open-field burning is the pollution caused by the release of particulate matter into the atmosphere. The effect of finer particulate matter, especially that of a size of less than $2.5 \mathrm{~mm}$ (PM 2.5), can reduce visibility into the atmosphere and deteriorate air quality even at the farthest places like highways, airports, etc., causing serious hazards for humans, even those who are far away from the sources of burning [10]. Consequently, the contribution of particulate matter in the atmosphere due to the biomass burning stood at $21 \%$ [10]. The smog fumes emitted during the burning of crop residue, under the effect of air circulation, can travel to significant distances, thus transporting with them various pollutants, causing serious haze conditions in local, regional, and global atmosphere [11]. It is also important to note here that although open burning is mostly done in rural areas, under the effect of air circulation its effects can be felt in the most remote areas and in neighboring provinces and countries as well [12]. Such a phenomenon was observed in Pakistan and India in 2016. Later, the images released (Figure 2) by NASA showed a huge amount of open burning of straw in Indian Punjab in November 2016, which most probably contributed to the poisonous smog in India and many adjacent areas of Pakistan [13]. Such a phenomenon was also observed in China [2,7]. A few of the examples of crop residue that are often burned in open fields are rice husk, wheat straw, etc. This study focuses on the proper disposal of wheat straw, as it is of prime importance, especially in countries where it is produced in huge quantities.

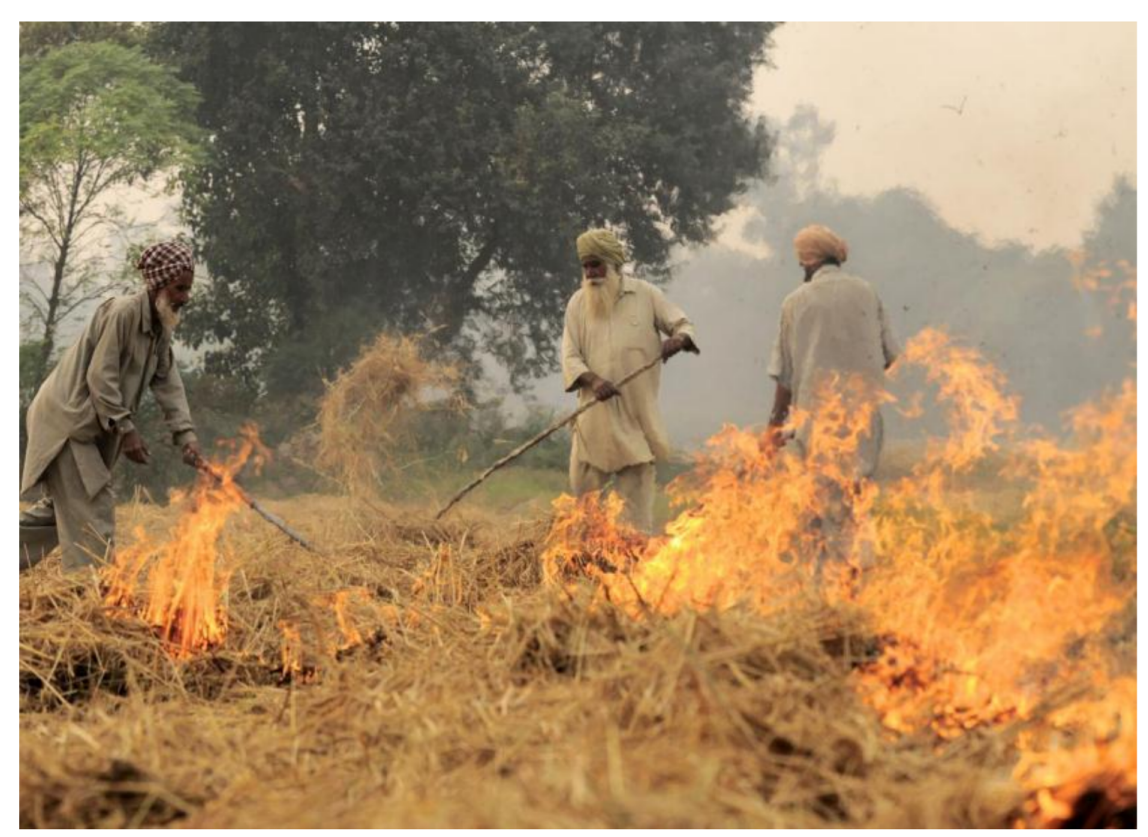

Figure 1. Farmers openly burning wheat straw in a field [14]. 


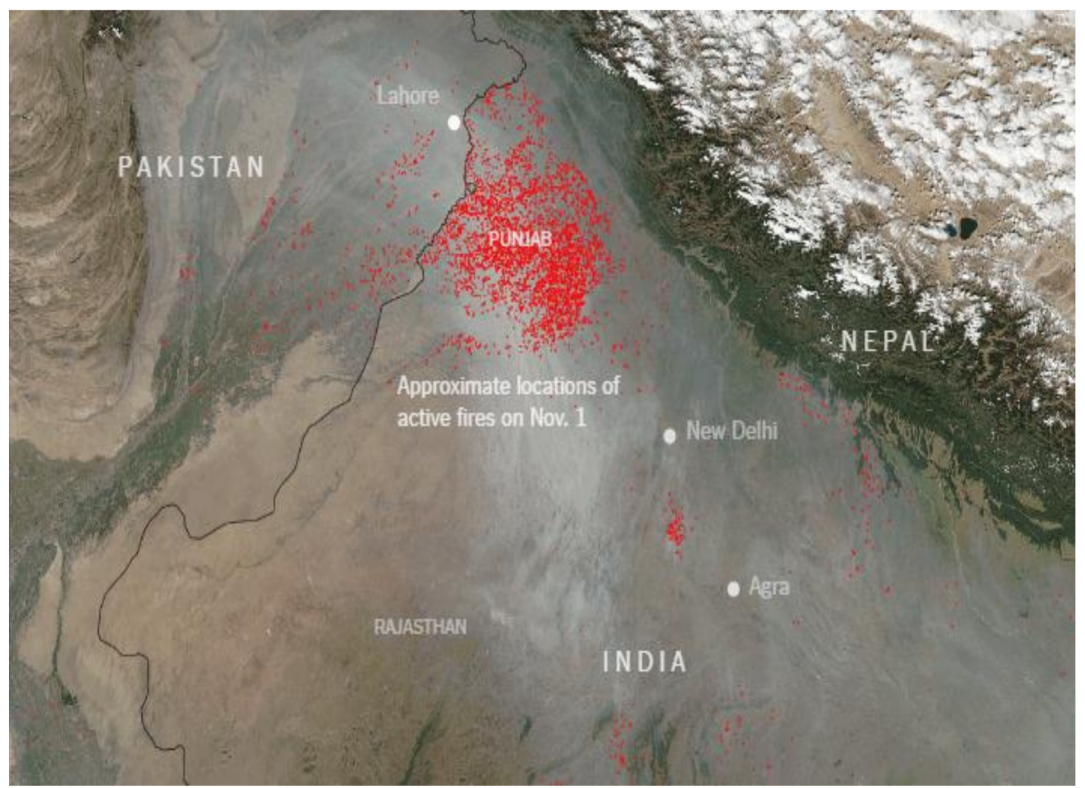

Figure 2. NASA Image showing open-field burning in Indian Punjab in November 2016 [13].

According to the statistics of Food and Agriculture Organization of the United Nations, the global annual production of wheat in 2015 was estimated to be 734.5 Million tons (Mt) [15]. Wheat straw is an agricultural by-product, obtained after stalks and chaffs of the wheat plant have been removed. On average, wheat straw yield is around 1.3-1.4 $\mathrm{kg}$ for each $\mathrm{kg}$ of grain produced [16]. Considering this, around $534 \mathrm{Mt}$ of wheat straw is produced globally. Therefore, a lot of wheat straw is left and is mostly burnt in open fields. However, a number of alternate methods have seen suggested to open burning, i.e., the incorporation of straw back to soil [17], using it to fuel energy production [18], using it as feed for cattle [19], and turning it into compost and then returning it to the soil [20]. However, each of these alternatives has some inherent drawbacks [21]. However, this research suggests an alternative method to dispose wheat straw, i.e., incineration. Incineration is a waste treatment process of burning of waste in a controlled environment. The major advantage of incineration is that it reduces the volume of waste up to $85-90 \%$, consequently reducing the requirement of landfill sites [22,23]. This factor becomes particularly important in countries like Japan, where land is already a scarce resource, and in urban areas where demand for land is extremely high. By employing various waste to energy processes, many developed countries are also generating energy by incineration [24]. This energy could be further used to produce electricity [22] and resulting ash can be used in the construction industry. Also, as this energy is from biomass, it would not add much to the net $\mathrm{CO} 2$ in the ecosystem [25]. In many developing countries like Pakistan, there is a shortage of electricity; hence, wheat straw (which is available locally in abundant quantity) could provide a short term solution to meet the energy demand of the country. In a study conducted on bagasse ash, it was concluded that $8 \%$ of the electricity requirement of Pakistan could be met by the use of bagasse, a similar type of agricultural waste material [26].

The production of cement is also a non-environmentally friendly process, as one ton of cement production requires around 1.6 MWh energy and discharges about one ton of carbon dioxide into the atmosphere [27]. Along with $\mathrm{CO}_{2}$ emission, sulfur oxide, nitrogen oxide, and particulates are significantly emitted during cement production. According to the estimate, one ton of cement production requires 3 to 6 million Btu energy and 1.7 tons of raw material [28]. Currently, the cement industry alone contributes around $7 \%$ of total $\mathrm{CO}_{2}$ emission worldwide, which is quite high [29]. The majority of the discharged $\mathrm{CO}_{2}$ in the atmosphere results from the decarbonisation of calcite in the cement clinker, the burning process, and the required electrical power [30]. Thus, this contributes to 
various environmental problems, rendering traditional concrete non-environmentally friendly and, consequently, producing a negative effect upon sustainable development. [31] Therefore, the alternative method suggested in this research would achieve multiple objectives, i.e., the safe disposal of wheat straw, aiding in the production of eco-friendly cement based composites, the sustainable consumption of raw material expended during the production of cement, and reducing the costs of construction [32]. It would also add economic value to the wheat straw, thus creating an incentive for the farmer to refrain from open burning of wheat straw. Among the other crop residue, successful investigations have been done on rice husk ash, bagasse ash, etc., for their use in cement based composites [33-38]. However, as per the authors' knowledge, until now, no systematic study has been devised to assess the most favorable conditions of controlled burning and grinding for production of wheat straw ash (WSA) that best-suited to its use in cement-based composites. For example: How do different temperature and grinding conditions affect the pozzolanic property of WSA? What is the optimum burning temperature and grinding time for its use as pozzolan? These ambiguities are still to be answered.

Therefore, this research was conducted to explore the most favorable conditions, which can contribute to the production of the best quality WSA. It is pertinent to mention here that although the process of controlled burning is an energy-intensive process, like other biomass, wheat straw has a high amount of organic content (i.e., cellulose, hemicellulose, and lignin) and a high-energy content [39]. Hence, the optimum conditions for controlled burning could be easily incorporated into other waste to energy processes in which biomass is used as a source of energy [40] and electricity generation [41,42], and resulting ash could be used as cement replacement.

\section{Experimental Investigation}

\subsection{Materials}

\subsubsection{Cement}

Ordinary Portland cement conforming to ASTM standard C150 Type I was used. The fineness of cement was $2750 \mathrm{~cm}^{2} / \mathrm{g}$, while its specific gravity was 3.15 .

\subsubsection{Wheat Straw (WS)}

Wheat straw was obtained from wheat grown in the surrounding areas of Abbottabad, Pakistan. In order to obtain uniform calcination, wheat straw was crushed into smaller pieces of " 1 to 1.5 " length.

\subsubsection{Wheat Straw Ash (WSA)}

In order to obtain WSA, heat treatment was given to wheat straw in a muffle furnace at the rate of $10{ }^{\circ} \mathrm{C} / \mathrm{min}$. WS was subjected to temperatures ranging from 500 to $800{ }^{\circ} \mathrm{C}$ at $100{ }^{\circ} \mathrm{C}$ interval for $2 \mathrm{~h}$ [43]. In order to avoid over and under burning, $1^{\prime \prime}$ thick sample was kept in the dish. After $2 \mathrm{~h}$ of control heating, the sample was taken out from the furnace and was allowed to cool in open air. A nomenclature was also adopted to identify different ashes. WSA500, WSA600, WSA700, and WSA800 denote ashes calcined at $500{ }^{\circ} \mathrm{C}, 600{ }^{\circ} \mathrm{C}, 700{ }^{\circ} \mathrm{C}$, and $800^{\circ} \mathrm{C}$ for $2 \mathrm{~h}$, respectively. It is also important to mention here that each sample of WSA was ground for sufficient time ( $30 \pm 5 \mathrm{~min})$ in ceramic ball mill and operated at $66 \mathrm{rpm}$ with grinding media to WSA ratio of 5 by weight before being used in calcination phase [44]. The $30 \pm 5 \mathrm{~min}$ time was selected using different trials until fineness of each WSA sample reached the fineness of cement, i.e., $2750 \mathrm{~cm}^{2} / \mathrm{gm}$.

\subsubsection{Water}

There is a small quantity of hardness in tap water due to presence of salts, which can react differently with ashes calcined at different temperatures, since mineralogical composition changes with incineration (Table 1). Therefore, for the consistency of the results, distilled water was used throughout the experimental program. 


\subsection{Testing Program}

\subsubsection{Testing of Ashes at Different Calcination Temperatures (Phase I)}

The quantity of silica plays an important role in pozzolanic performance of a material [45]. Therefore, to check the chemical composition, XRF analysis was performed on WSA produced after calcination. Loss on ignition test was carried out as per ASTM standard C311 and C114.

Mineralogical qualitative characteristics of WSA were studied by XRD, using differactrometer model JDX-3532 JEOL, Japan with CuK $\alpha$ radiation (1.5418 $\AA$ ) operated at $40 \mathrm{kV}$ and $25 \mathrm{~mA}$ with a $2 \theta$ scan between $20^{\circ}$ and $80^{\circ}$. The diffraction pattern from ICDD was used to identify the chemical phases of the samples by using "MATCH Phase Identification from Powder v3.1" software.

Pozzolanic Activity Index (PAI) was determined to see whether use of WSA with cement results in adequate strength development or not. Test was performed on cubes at 7 and 28 days of curing by replacing $20 \%$ cement by weight of ash. One control mix and four WSA blended mixes were cast for respective ashes burnt at 500,600,700, and $800{ }^{\circ} \mathrm{C}$. Water/binder ratio was kept at 0.484 . Pozzolanic activity Index was then calculated as per ASTM C311 [46] using the following formula:

$$
\text { Pozzolanic Activity index }=(\mathrm{A} / \mathrm{B}) \times 100
$$

$\mathrm{A}=$ average compressive strength of ash blended cubes, $\mathrm{MPa}$ (psi), and

$\mathrm{B}=$ average compressive strength of control mix cubes, $\mathrm{MPa}(\mathrm{psi})$.

The pozzolanic activity of WSA was also assessed by Fratini and Chapelle tests. Fratini test method is based on British Standard BS EN 196 [47]. Blend of $2 \mathrm{~g}$ of ash and $18 \mathrm{~g}$ of cement was poured in $100 \mathrm{~mL}$ of distilled water and kept in oven for 8 days at $40^{\circ} \mathrm{C}$ in a sealed container. After 8 days, sample was filtered through $2.7 \mu \mathrm{m}$ filter paper under vacuum for $30 \mathrm{~s} .25 \mathrm{~mL}$ of filtrate was pipetted in a flask and titrated against $0.1 \mathrm{M} \mathrm{HCL}$ solution in the presence of methyl orange as indicator to determine concentration of $[\mathrm{OH}]^{-1}$. $[\mathrm{Ca}]^{2+}$ concentration was determined by atomic absorption spectroscopy. Determined $[\mathrm{OH}]^{-1}$ and $[\mathrm{Ca}]^{2+}$ expressed as equivalent $\mathrm{CaO}$ concentration was plotted on lime solubility curve graph to assess pozzolanic activity. Free lime $\left(\mathrm{Ca}(\mathrm{OH})_{2}\right)$ was consumed during pozzolanic action; so, for a material to be active, pozzolan should lie below the solubility curve.

Chapelle test was conducted to determine the consumption of free lime in terms of $\mathrm{mg} \mathrm{Ca}(\mathrm{OH})_{2}$ fixed per gram of pozzolan as per French Norm NF P 18-513 [48]. $1 \mathrm{~g} \mathrm{CaO}, 1 \mathrm{~g}$ ash, and $250 \mathrm{~mL}$ of distilled water were heated in oven at $90^{\circ} \mathrm{C}$ for $16 \mathrm{~h}$ in sealed container. Controlled samples were formulated with just $\mathrm{CaO}$ under similar conditions. After $16 \mathrm{~h}$, the sample was cooled down to room temperature, and free $\mathrm{Ca}(\mathrm{OH})_{2}$ was extracted from sample by adding $250 \mathrm{~mL}$ of sucrose solution prepared by adding $60 \mathrm{~g}$ of sucrose in $250 \mathrm{~mL}$ of water. The sample was then filtered under vacuum suction applied for $30 \mathrm{~s}$. Subsequently, $25 \mathrm{~mL}$ of filtrate was pipetted, and free lime was determined by titrating against $0.1 \mathrm{~N} \mathrm{HCL}$ solution and phenolphthalein as indicator.

\subsubsection{Testing of Ashes at Different Grinding Times (Phase II)}

After determining optimum temperature, the ashes were tested to evaluate the effect of fineness and specific surface area upon their pozzolanic activity. For this purpose, ashes were ground for duration of 15, 30, 60, 120, and $240 \mathrm{~min}$ in ball mill operated at $66 \mathrm{rpm}$ with grinding media to WSA ratio of 5 by weight [44]. Pozzolanic activity index, Fratini Test and Chapelle tests were again conducted for different grinding regimes. A nomenclature was also adopted to identify different ashes. WSA0 denotes ash without grinding, while WSA15, WSA30, WSA60 WSA120, and WSA240 represent ashes ground for duration of $15,30,60,120$, and $240 \mathrm{~min}$, respectively.

In order to evaluate the effect of grinding upon the total particle surface area, Blaine fineness values were determined according to ASTM C204 [49], while the morphology of WSA was evaluated by using SEM at different grinding periods using model JSM-5910 JEOL, Japan at an acceleration voltage of $30 \mathrm{kV}$ with secondary electrons. 


\section{Test Results and Discussion}

\subsection{Micro Morphology Analysis of Wheat Straw}

The morphology of WS was determined by capturing Scanning Electron Microscopy images of cross-section and surface, as shown in Figure 3. It can be seen in cross section (Figure 3a) that inner layers are composed of interconnected thin walled tubules, while outer cover (Figure 3b) is also composed of interconnected channels but with smaller diameters. The outer covering is much denser and compact compared to inner layers, and channels with sizes of up to $10 \mu \mathrm{m}$ diameter can be observed in outer layers compared to $70 \mu \mathrm{m}$ found in inner layers. The SEM image of the surface shows that inner layers contain number of small surface pores of diameter up to $5 \mu \mathrm{m}$, while outer layers are composed of relatively thick sheet and are without any surface pores.

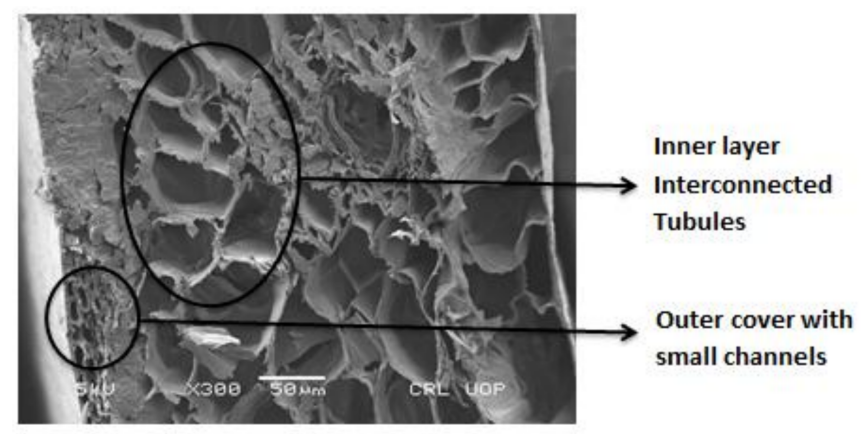

(a)

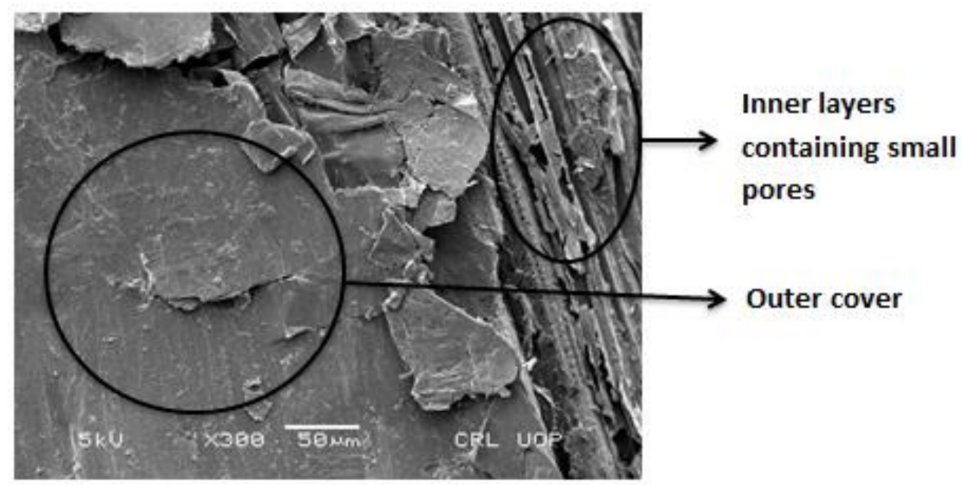

(b)

Figure 3. SEM of wheat straw sample collected from Abbottabad: (a) cross section, (b) outer cover.

\subsection{Phase-I (Calcination)}

It is known from literature that in order to use agricultural waste materials in cement-based materials, they have to be calcined [50-53]. Combustion temperature and time are important factors in determining whether silica remains amorphous or crystalline in ash. In this research, the WS samples were calcined for $2 \mathrm{~h}$ at different temperatures. The results of calcination are discussed in this section.

\subsubsection{Color Change}

The color of the ash produced after calcination is an indirect indicator of the quality of produced ashes, as dark-colored ash represents incomplete burning. The dark color is due to the presence of unburnt carbon, which is not desired [54]. Figure 4 shows color change of WSA500, WSA600, WSA700, and WSA800. WSA500 shows that a large number of carbon particles are present in the ash, and that complete burning has not occurred yet. The unburnt carbon not only induces poor pozzolanic activity but also degrades durability properties of cement-based material [55]. Furthermore, unburnt carbon 
tends to hamper the cement paste hydration and increases the water demand due to porous structure, thus decreasing the compressive strength. As the temperature increases to $600{ }^{\circ} \mathrm{C}$, WSA600 is whitish grey and is comparatively brighter than WSA500, indicating an increased removal of fixed carbon. Also, the presence of bright-colored particles has increased, indicating an improvement in quality of calcined ash. However, there is still some amount of unburnt carbon present, as evident by presence of black particles. WSA700 is brighter and brownish in color, with very small amount of grey-colored particles present. Similarly, WSA800 is also significantly brownish in color, signifying further removal of unburnt carbon and thus adequate burning. For RHA, calcined at $800{ }^{\circ} \mathrm{C}$ for $2 \mathrm{~h}, \mathrm{Xu}$ et al. [43] showed that number of black particles decreased, while number of white creamy particles represented by bright appearance of ash increased due to improved oxidation of carbon at this temperature. Different colors can be attained depending upon the variation in amount of oxides present in the material $[56,57]$.

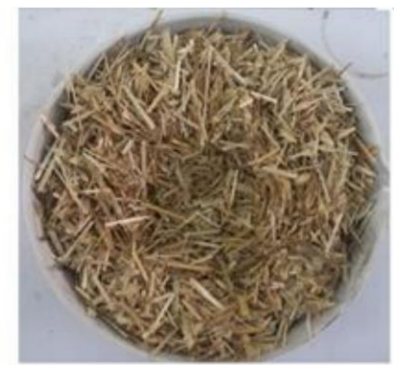

(a)

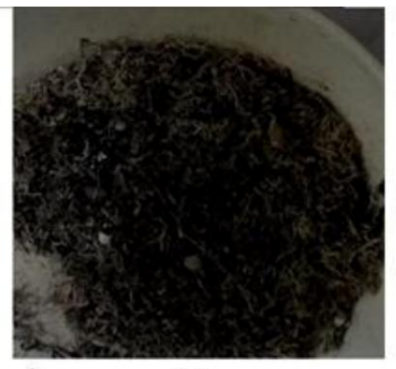

(b)

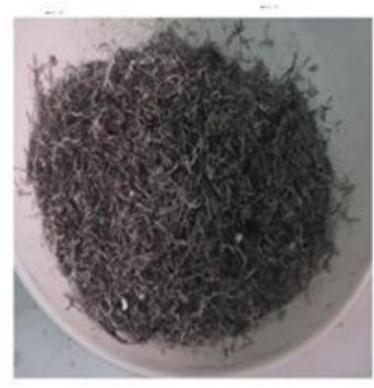

(c)

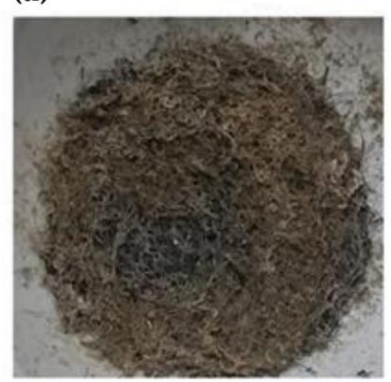

(d)

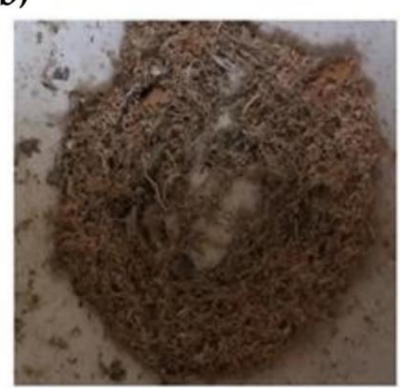

(e)

Figure 4. Color change of (a) WSA before burning, (b) WSA500, (c) WSA600, (d) WSA700, and (e) WSA 800 .

\subsubsection{X-ray Fluorescence (XRF)}

XRF was performed on WSA500, WSA600, WSA700, and WSA800 to analyze the effect of calcination temperatures upon the chemical compositions of the ashes, and the results are tabulated in Table 1. The minerals and silicates observed in the ashes are obtained by the plants from the soil they grow in, and the amount of these compounds depends upon the soil in which the plant grows [58]. Therefore, WS composition is expected to differ from place to place. However, the observed composition of the WSA ashes is in line with that reported in literature [59,60]. High values of silica content and loss on ignition (associated with the presence of residual carbon, as well as metallic impurities) can be observed. The ashes WSA500 and WSA600 contain significant quantity of $\mathrm{K}_{2} \mathrm{O}$, which turns these ashes dark gray [45]. According to the standard ASTM C618 [61], in order for a material to be classified as a pozzolan, its $\left(\mathrm{SiO}_{2}+\mathrm{Al}_{2} \mathrm{O}_{3}+\mathrm{Fe}_{2} \mathrm{O}_{3}\right)$ should be equal to or greater than $70 \%$. Except for WSA500, all the ashes qualify as pozzolanic material according to this standard. WSA600 shows highest silica content, and consequently highest quantity of $\left(\mathrm{SiO}_{2}+\mathrm{Al}_{2} \mathrm{O}_{3}+\mathrm{Fe}_{2} \mathrm{O}_{3}=80.16 \%\right)$. The percentage of these oxides varies depending upon the type of minerals. Typical values of these oxides are $80 \%$, $85 \%, 91 \%, 90 \%$, and $74 \%$ in case of calcined clay, Fly ash class F, silica fume, rice husk, and SCBA, 
respectively $[62,63]$. Based on chemical composition results, it can be concluded that calcination temperature of $600^{\circ} \mathrm{C}$ is the optimum temperature for producing maximum silica in WSA.

The value of LOI, which is primarily an indicator of amount of unburnt carbon, is represented according to various colors of the produced ashes. ASTM618 [61] requires a LOI value of less than $6 \%$ for adequate performance of a pozzolan, which all ashes except WSA500 satisfy. The results indicate that for temperature greater than $500{ }^{\circ} \mathrm{C}$, the calcination conditions adopted in this research are sufficient to remove the carbon and volatile compounds. It can also be observed that as the temperature for the calcination increases, the value of LOI decreases. This is due to better oxidation of carbon particles at higher temperatures [43]. Similar results were observed for sugar cane bagasse ash, in which the researchers showed that LOI decreases with the increase in temperature from 400 to $800{ }^{\circ} \mathrm{C}$ [53]. The WSA500 sample shows highest value of LOI, i.e., $12.8 \%$, thus indicating presence of unburnt carbon, which is also evident from the color of black ash produced at this temperature. WSA600 shows a decreased LOI value of $5.8 \%$, which shows that significant amount of carbon has been oxidized. This is also validated by the slightly gray color of WSA600; however, there are still few carbon particles present in it. The LOI value of WSA700 and WSA800 further decreases, indicating further fixation of carbon; this is also evident from the absence of black color in WSA700 and WSA800.

Table 1. Chemical composition of calcined wheat straw ashes.

\begin{tabular}{ccccc}
\hline Compounds (\%) & WSA-500 & WSA-600 & WSA-700 & WSA-800 \\
\hline $\mathrm{SiO}_{2}$ & 64.38 & 77.36 & 75.97 & 73.15 \\
$\mathrm{~K}_{2} \mathrm{O}$ & 8.51 & 5.43 & 3.25 & 3.87 \\
$\mathrm{Al}_{2} \mathrm{O}_{3}$ & 2.83 & 1.53 & 1.68 & 1.82 \\
$\mathrm{Fe}_{2} \mathrm{O}_{3}$ & 1.38 & 1.27 & 1.47 & 1.67 \\
$\mathrm{CaO}$ & 4.12 & 3.87 & 4.34 & 5.78 \\
$\mathrm{MgO}$ & 1.98 & 1.87 & 1.87 & 1.78 \\
$\mathrm{TiO}$ & 1.02 & 0.97 & 0.96 & 0.96 \\
$\mathrm{LOI}$ & 12.8 & 5.8 & 3.4 & 2.38 \\
$\left(\mathrm{SiO}_{2}+\mathrm{Al}_{2} \mathrm{O}_{3}+\mathrm{Fe}_{2} \mathrm{O}_{3}\right)$ & 68.6 & 80.16 & 79.12 & 76.64 \\
\hline
\end{tabular}

\subsubsection{Weight Loss}

Weight loss is also one of the parameters that is used to assess the effect of burning temperature upon the mass of the ashes obtained. When agricultural plants are heated from room temperature, organic matter like cellulose, lignin, etc., decomposes into carbon. Further rise in temperature causes oxidation of carbon, thus leading to loss of mass of the material that is being calcined [64]. Table 2 shows weight loss of WS ashes at various temperatures of calcination. It can be observed that weight loss increases with the increase in temperature. As expected, WSA800 shows highest weight loss of $91.5 \%$ and ash of $8.5 \%$. This is because of burning away of most of organic matter at this temperature. WSA600 shows a weight loss of $86 \%$ and an ash content of $14 \%$. The ash quantity is higher than that obtained in literature [65]; however, in this research, calcination duration was $2 \mathrm{~h}$, while the values reported in literature are for WSA, in which calcination was carried out for $5 \mathrm{~h}$. $\mathrm{Xu}$ et al. [43] calcined RHA at different temperatures for $2 \mathrm{~h}$ and found that the weight loss at $800{ }^{\circ} \mathrm{C}$ was maximum and was equal to $86 \%$.

Table 2. Weight loss of calcined wheat straw ashes.

\begin{tabular}{ccccc}
\hline Temperature $\left({ }^{\circ} \mathbf{C}\right)$ & W(g) Before & W(g) After & \% Ash Obtained & Weight Loss (\%) \\
\hline 500 & 30 & 7.47 & 24.9 & 75.1 \\
600 & 30 & 4.22 & 14 & 86 \\
700 & 30 & 4.56 & 11.8 & 88.2 \\
800 & 30 & 2.55 & 8.5 & 91.5 \\
\hline
\end{tabular}




\subsubsection{X-ray Diffractometry (XRD)}

After analyzing the ashes for the amount of unburnt carbon content and silica content, the third most important factor is to check the mineralogical phases (amorphous or crystalline) of silica in WSA. Therefore, XRD was performed for qualitative analysis of silica in WSA. It is reported that amorphous silica is much more reactive during pozzolanic reaction compared to crystalline silica [53]. Therefore WSA500, WSA600, WSA700, and WSA800 were analyzed by XRD. The XRD graphs obtained were analyzed by "MATCH Phase Identification from Powder v3.1" software to identify the peaks.

Figure 5 shows XRD patterns of various ashes. Intensity of peak is the difference between the top and bottom of the peak. For WSA500, a small sharp peak is observed at $\left(2 \theta=26.73^{\circ}\right)$, which is identified as quartz $\left(\mathrm{SiO}_{2}\right)$. However, the silica present in WSA500, is mostly in amorphous phase. The XRD of WSA600 (Figure 5) shows that intensity of peak $\left(\mathrm{SiO}_{2}\right)$ has decreased and is smallest compared to diffraction patterns at $2 \theta=26.73^{\circ}$ of all other ashes. This indicates that silica is mostly present in amorphous phase at $600{ }^{\circ} \mathrm{C}$. This is according to the research [66], which concludes that in order to produce amorphous silica, calcination temperature should be less than $700{ }^{\circ} \mathrm{C}$. However, the slight sharp peak at $\left(2 \theta=26.73^{\circ}\right)$ observed for WSA600 shows presence of a small quantity of crystalline silica. The samples WSA700 and WSA800 show very intense peaks of quartz, indicating that silica is predominantly crystalline at these temperatures. From XRD patterns of all the ashes, it can be concluded that in WSA600 and WSA500 samples, silica is mostly in amorphous phase as compared to WSA700 and WSA800 samples. In an investigation carried out by Cordeiro et al. [53] on sugar cane baggase ash, the authors concluded that in the temperature range $400-600{ }^{\circ} \mathrm{C}$, the ash was amorphous. Above $600{ }^{\circ} \mathrm{C}$, due to the increase in temperature, amorphous silica transformed into crystalline silica [53]. By comparing the results of color change at $700{ }^{\circ} \mathrm{C}$ and $800^{\circ} \mathrm{C}$ with XRD, it can be deduced that greater amount of carbon residues was removed from WSA samples (as clear from their bright colors), with the consequence that silica was transformed to crystalline form.

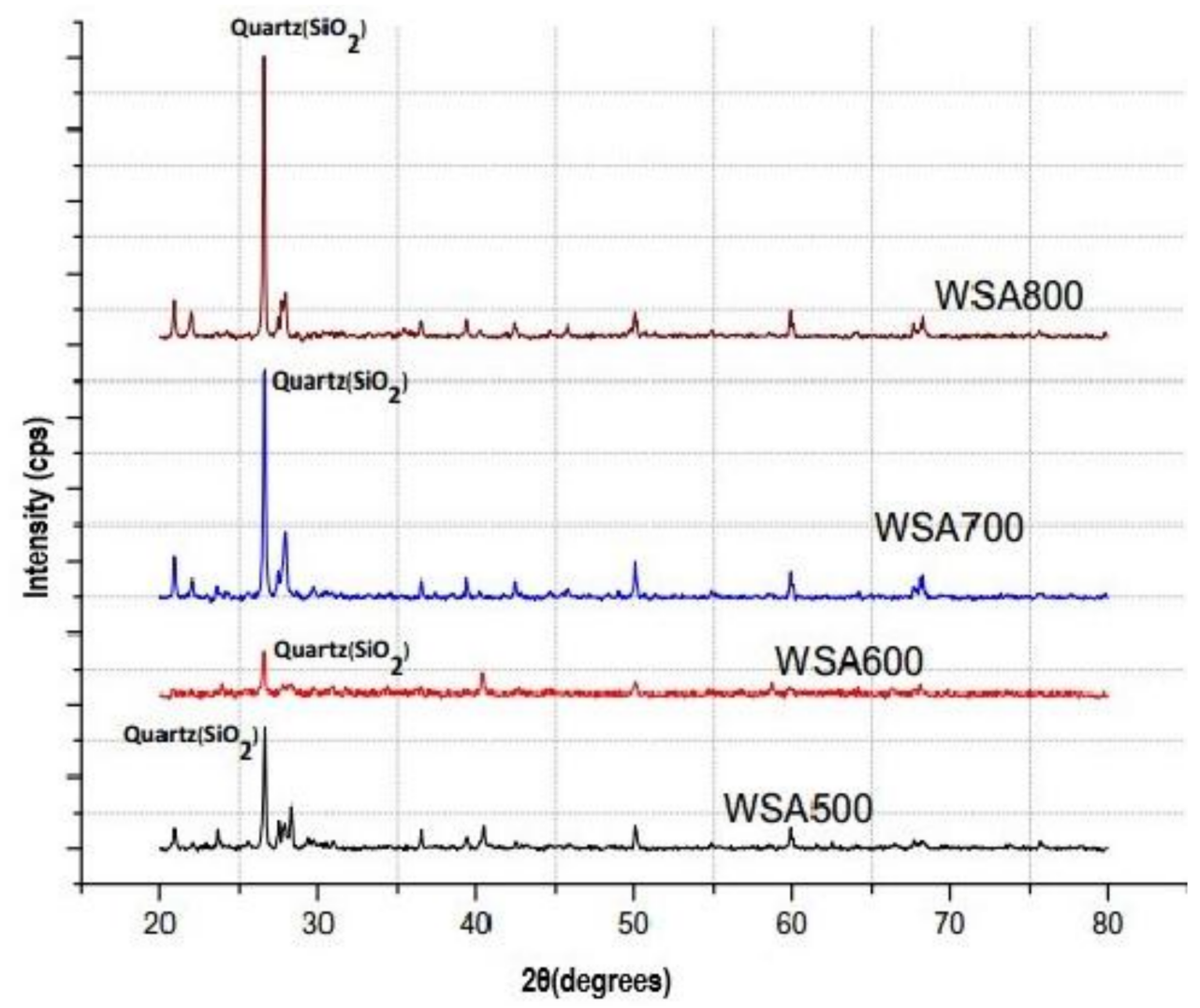

Figure 5. XRD Patterns of calcined wheat straw ashes at different temperatures. 


\subsubsection{Fratini Test}

Fratini test is qualitative test, which is based upon the amount of lime consumed by the pozzolan. The more a pozzolan consumes lime, the better its performance. The results of Fratini test are shown in Figure 6. It can be observed from the graph that all ashes show pozzolanic activity, except WSA800, as it lies above the solubility curve, indicating very minute or no pozzolanic activity. This is due to the presence of highly crystalline silica. WSA600 shows highest pozzolanic activity according to the Fratini test, because it is lying in the lowest region, indicating highest amount of $\mathrm{Ca}(\mathrm{OH})_{2}$ consumed by this ash. This behavior validates the XRD and XRF results. WSA700 and WSA500 show pozzolanic activity to varying degrees, but less than WSA600 due to more presence of crystalline silica in WSA700 and more unburnt carbon in WSA500. Moreover, pozzolanic activity of WSA500 is more than WSA800, indicating that existence of crystalline silica adversely affects the pozzolanic activity when compared with existence of unburnt carbon. Bahurudeen and Santhanam [67] used Fratini test to find the pozzolanic reactivity of bagasse ash samples including fibrous particles, sieved sample, white particles, and SG (sieved and ground) sample. Test results showed that white particles (sample burnt above $700{ }^{\circ} \mathrm{C}$ ), fibrous particles, and raw bagasse ash showed no or insufficient pozzolanic reactivity. Hence, the shape and color of ash sample, which was influenced by calcination and grinding, has influence on pozzolanic reactivity. It is therefore suggested that, in future research, the shape of samples obtained at different calcination and its influence on pozzolanic reactivity should be investigated.

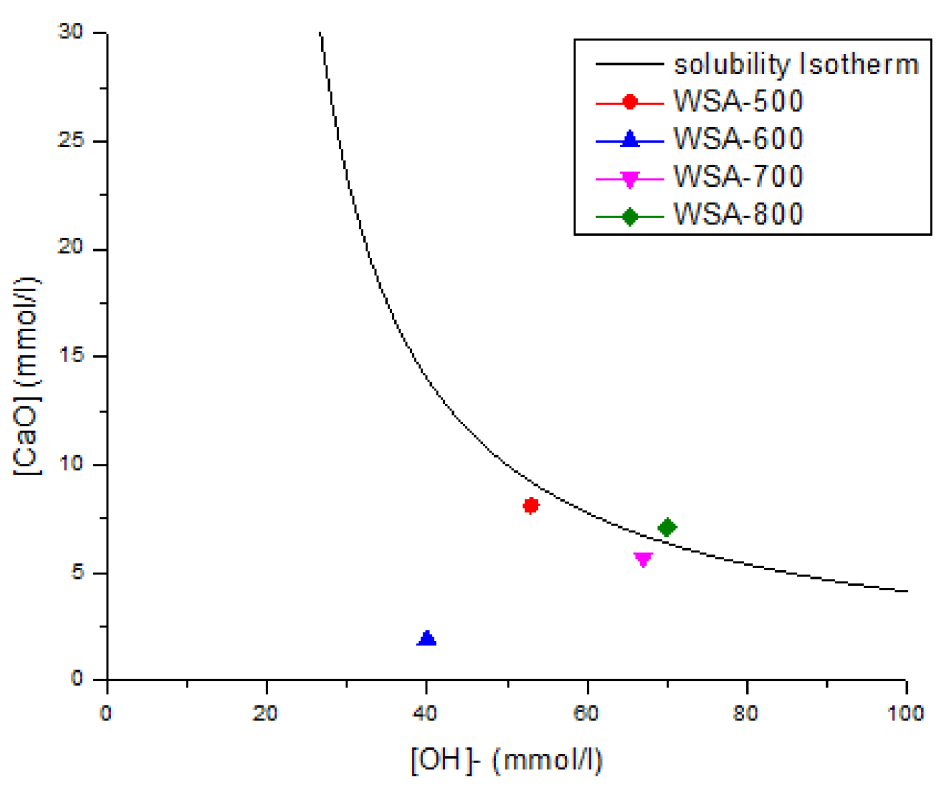

Figure 6. Solubility isotherm of Fratini Test at different calcination temperatures.

\subsubsection{Chapelle Test}

The results of Chapelle method are presented in the Figure 7. Various ashes show varying degrees of pozzolanic activity. WSA600 shows highest Chapelle activity of $453.51 \mathrm{mg} / \mathrm{g}$, which is $37.84 \%$ higher than the standard [48], i.e., $330 \mathrm{mg} / \mathrm{g}$. Again, the reasons cited for high Chapelle activity are presence of amorphous silica and a greater amount of $\mathrm{SiO}_{2}$ present in WSA600. From $600{ }^{\circ} \mathrm{C}$ onwards, Chapelle activity decreases. WSA700 shows a pozzolanic activity of $375.32 \mathrm{mg} / \mathrm{g}$, which is $14 \%$ higher than the standard, while WSA800 shows lowest Chapelle activity with value just equal to minimum required by standard. Also, WSA500 shows more Chapelle activity with respect to WSA700 and WSA800, pointing to the fact that presence of crystalline silica had a more adverse effect upon the Chapelle activity than presence of unburnt carbon in WSA500. Moreover, in WSA500 organic matter is more in terms of unburnt carbon, which absorbs calcium ions, rendering good results [68]. 


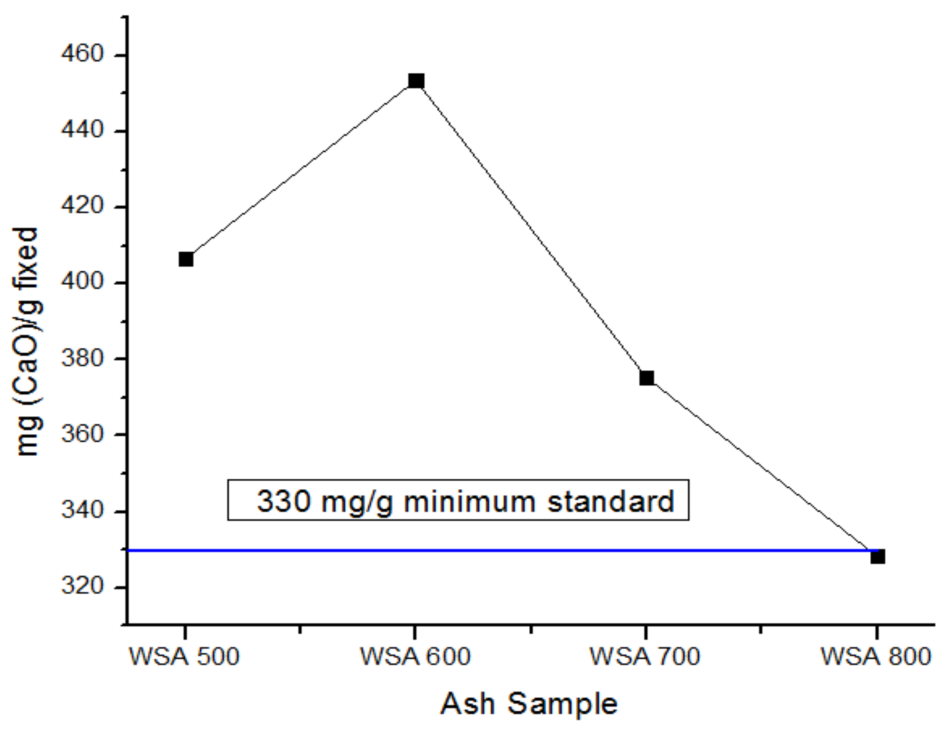

Figure 7. Relation between calcination temperature and Chapelle activity for WSA samples.

\subsubsection{Pozzolanic Activity Index (PAI)}

PAI is the most important of all the tests, as it is a gauge for compressive strength, which is a prime factor in designing of civil structures. Table 3 shows the results of pozzolanic activity index when WSA was used as $20 \%$ replacement (by mass) of cement. It is noted that as per PAI results, WSA500 and WSA600 qualify for pozzolanic material at 28 days according to ASTM C618 [61], which requires a PAI greater than $75 \%$ for a material to be classified as pozzolan, while in case of 7 days PAI, none of the samples qualify for pozzolanic material. The highest 7 and 28 days PAI is found in case of WSA600 and is due to the presence of amorphous silica. The pozzolanic reaction was not efficient enough in WSA700 and WSA800 due to presence of crystalline phases of silica, and thus resulted in low 7 and 28 days PAI. The PAI at 28 days for WSA700 and WSA800 was found to be $57.8 \%$ and $58.1 \%$ respectively. Also, PAI of WSA500 is $77.5 \%$ at 28 days, which is greater than that of WSA700 and WSA800, thus pointing to the fact that presence of crystalline silica had a greater negative effect upon the pozzolanic reaction compared to presence of unburnt carbon (WSA500 contains more unburnt carbon than WSA700 and WSA800). A similar trend was also observed in Chapelle activity results. This validates the fact that presence of amorphous silica in pozzolan is one of the most important parameters for its adequate performance. Cordeiro et al. [53] investigated PAI of sugarcane bagasse ash that was first burnt at $350{ }^{\circ} \mathrm{C}$ for $3 \mathrm{~h}$ and then for another $3 \mathrm{~h}$ at $400-800{ }^{\circ} \mathrm{C}$ with increment of $100{ }^{\circ} \mathrm{C}$. Test results showed that the sugarcane bagasse ash burnt at $600^{\circ} \mathrm{C}$ met the requirement of PAI as per Brazilian standard. Bahurudeen and Santhanam [67] determined the PAI of Bagasse ash obtained from cogeneration boiler burnt at $500-550{ }^{\circ} \mathrm{C}$. The ash was further burnt at $600-900{ }^{\circ} \mathrm{C}$ with increment of $100{ }^{\circ} \mathrm{C}$ for $90 \mathrm{~min}$. According to the authors, the PAI increased up to $700{ }^{\circ} \mathrm{C}$ and then subsequently decreased with the increase in temperature. The samples calcined at $700{ }^{\circ} \mathrm{C}$ and $800{ }^{\circ} \mathrm{C}$ achieved the minimum Pozzolanic activity Index set by ASTM to be classified as pozzolan. The difference in results is believed to be due to difference in calcination time, which is also one of the important parameters influencing PAI of ashes. Moreover, specific surface area is another parameter affecting the PAI and hence is discussed in the next section.

The results of difference in compressive strength between 7 and 28 days are presented in Figure 8 . It can be observed that difference in strength is more in case of WSA500 as compared to control mix, while in case of WSA700 and WSA800 difference is less. The difference in case of WSA500 is the highest (7.33 MPa), indicating highest rate of gain of strength in mix WSA500. One reason why WSA500 shows the lowest initial strength is because organic matter in terms of unburnt carbon preferentially retarded the hydration through nucleation and complexion during early age $[69,70]$. The increased difference in 
compressive strength of WSA600 mix can be explained on the basis of pozzolanic activity. The least difference in strength has been reported for WSA700 and WSA800 due to presence of inactive crystals, which render the pozzolanic reaction inert as confirmed by XRD results.

Table 3. Results of PAI of WSA blended cement cubes, w/c ratio: 0.484.

\begin{tabular}{ccccc}
\hline & $\begin{array}{c}\text { 7 Days Strength } \\
\text { (MPa) }\end{array}$ & $\begin{array}{c}\text { 7 Days Pozzolanic Activity } \\
\text { Index (\%) }\end{array}$ & $\begin{array}{c}\text { 28 Days Strength } \\
\text { (MPa) }\end{array}$ & $\begin{array}{c}\text { 28 Days Pozzolanic Activity } \\
\text { Index (\%) }\end{array}$ \\
\hline Control & 11 & 100 & 15.73 & 100 \\
WSA500 & 4.90 & 44.5 & 12.23 & 77.5 \\
WSA600 & 7.10 & 64.5 & 13.4 & 85.2 \\
WSA700 & 4.73 & 43.0 & 9.10 & 57.8 \\
WSA800 & 4.85 & 44.1 & 9.15 & 58.1 \\
\hline
\end{tabular}

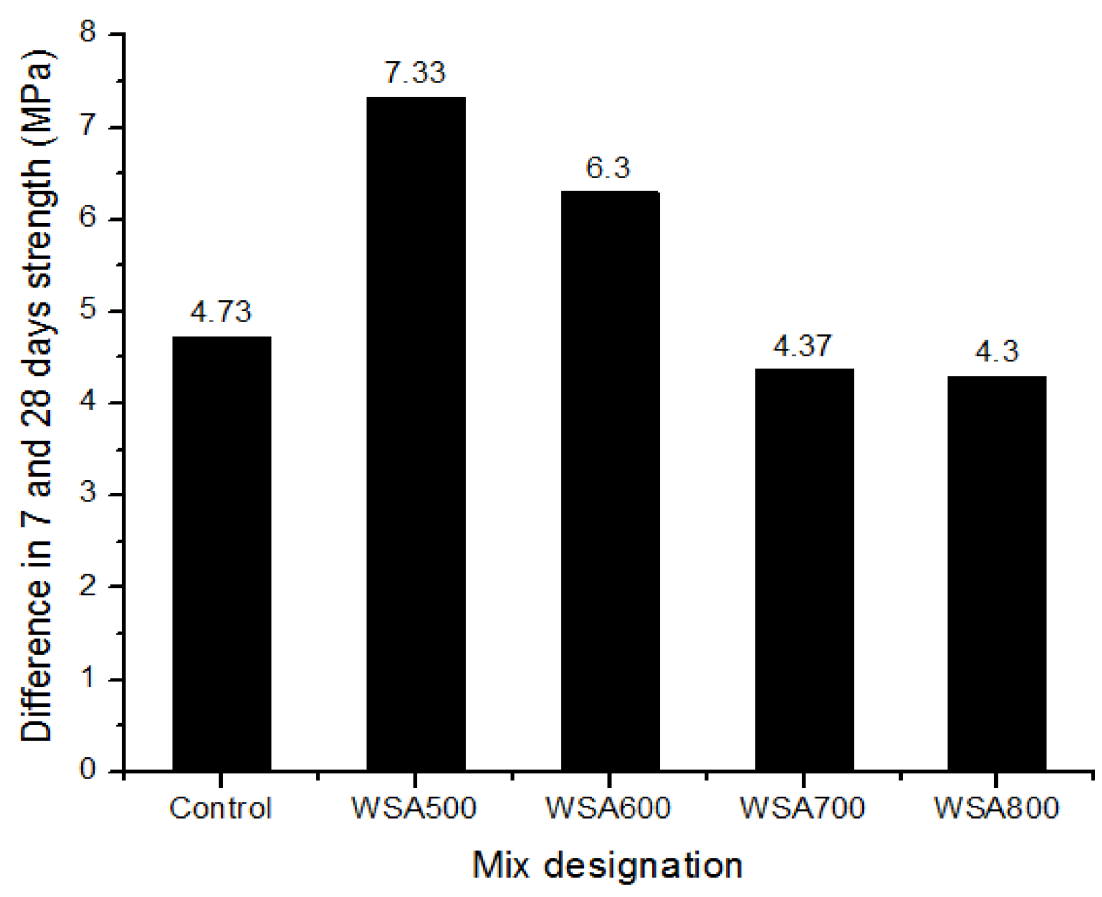

Figure 8. Difference in compressive strength of WSA samples between 7 and 28 days.

Based on XRF, XRD, Chapelle, Fratini, and PAI tests, the best calcination temperature was found to be $600{ }^{\circ} \mathrm{C}$ and hence was used in the subsequent phase. The resulting ash obtained at this temperature can become a value-added product for industry, in which agricultural waste such as bagasse is usually burnt at round $550{ }^{\circ} \mathrm{C}$ in cogeneration boiler to utilize its maximum fuel value [67].

\subsection{Phase-II (Grinding)}

After determining optimum temperature, the ashes were ground for different durations $(15,30$, 60,120 , and $240 \mathrm{~min}$ ) to evaluate the effect of fineness and specific surface area upon their pozzolanic activity. The results are presented and discussed in this section.

\subsubsection{Blaine Fineness (Grinding)}

As discussed earlier, specific surface area is yet another very important parameter of pozzolanic activity. When ashes are ground, their particle size reduces, and thus specific surface area increases. The results of Blaine fineness are shown in Table 4. It can be observed that up to 30 min of grinding there is an insignificant increase in Blaine surface area of just $11 \%$ with respect to WSA before grinding, while an increase of $28 \%$ is observed in Blaine surface area after 60 min of grinding. 
The micro morphology of WSA ground after 60 min shows significant breaking of particles (Figure 9a). The WSA60 shows coarser quartz particles, which are identified by their conchoidal fractures [71]. Due to the breakage of particles up to $60 \mathrm{~min}$ of grinding, the Blaine surface area has increased. The increase in surface area after $120 \mathrm{~min}$ and $240 \mathrm{~min}$ with respect to WSA without grinding is $48 \%$ and $68 \%$, respectively. As the grinding duration increases, the grains break down further due to the mechanical action of the grinding media, resulting in increased fineness of the material [72]. This is observed in (Figure 9b,c), in which WSA120 shows a heterogeneous mixture of large number of finer and few coarser particles. In WSA240, the amount of finer particles has increased even more. Increased specific surface area helps in pozzolanic reaction by providing more nucleation sites for precipitation of the reactants, and thus enhancing the rate of pozzolanic reaction [73]. Similarly, small particles of ground WSA can fill the voids or air spaces in the cement/concrete structure and thus can produce denser concrete. This is referred to as the filler or packing effect [74]. The percentage increase in surface area for WSA120 with respect to WSA60 is approximately $16 \%$, while the percentage increase in surface area for WSA240 with respect to WSA120 is approximately $13 \%$. The decrease may be related to the inherent difficulty in grinding fine particles associated with their strength, low capture probability, and their tendency to agglomerate [75]. It is important to point out here that the grinding technique adopted in this research did not result in significant increase in Blaine surface area as compared to other studies reported in literature. For example, Cordeiro et al. [73] reported an increase of $510.47 \%$ after grinding SCBA for $240 \mathrm{~min}$. The SCBA without grinding had a Blaine surface area of $1960 \mathrm{~cm}^{2} / \mathrm{g}$, while after $240 \mathrm{~min}$ of grinding, the surface area of SCBA increased to $11,970 \mathrm{~cm}^{2} / \mathrm{g}$. Similarly, $\mathrm{Xu}$ et al. [76] ground the RHA from $5 \mathrm{~min}$ to $120 \mathrm{~min}$ and found that Blaine surface area increases up to $30 \mathrm{~min}\left(19,558 \mathrm{~cm}^{2} / \mathrm{g}\right)$, and then it started decreasing. The authors found that this was due to the agglomeration of RHA particles due to excessive grinding duration. The difference in results is due to the reason that the ball mill used in this research had a speed of $66 \mathrm{rpm}$, due to which no tumbling motion of the grinding media was observed, which is very important for efficient grinding [44].

Table 4. Results of Blaine Fineness of WSA samples.

\begin{tabular}{ccc}
\hline & Blaine Surface Area $\mathbf{( \mathbf { c m } ^ { 2 } / \mathbf { g } )}$ & \%Increase in Surface Area w.r.t without Grinding \\
\hline WSA0 & 2480 & \\
WSA15 & 2579.9 & 4.03 \\
WSA30 & 2752.3 & 10.98 \\
WSA60 & 3174.9 & 28.02 \\
WSA120 & 3671.1 & 48.03 \\
WSA240 & 4166.6 & 68.01 \\
\hline
\end{tabular}

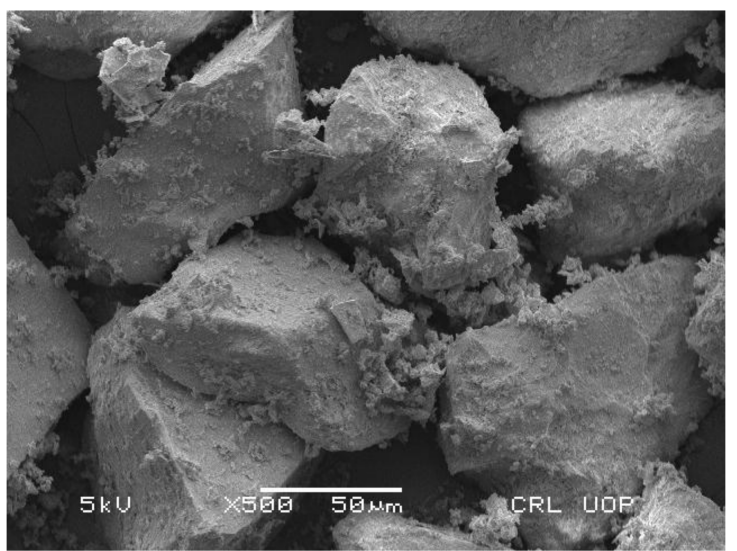

(a)

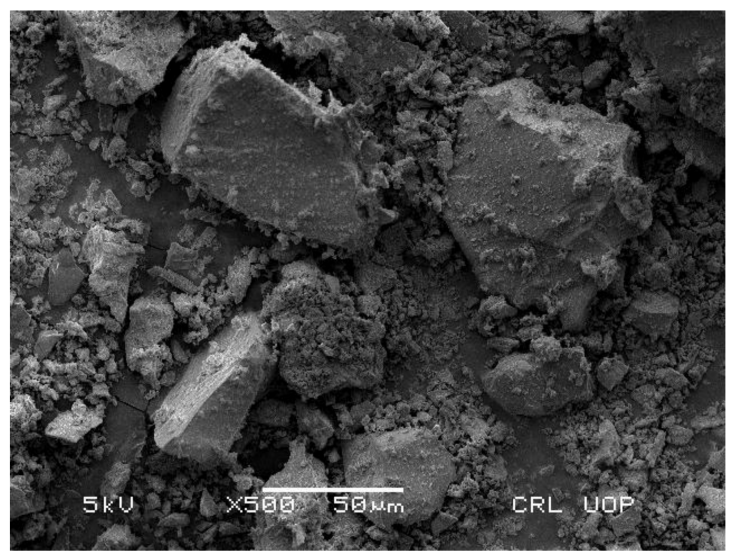

(b)

Figure 9. Cont. 


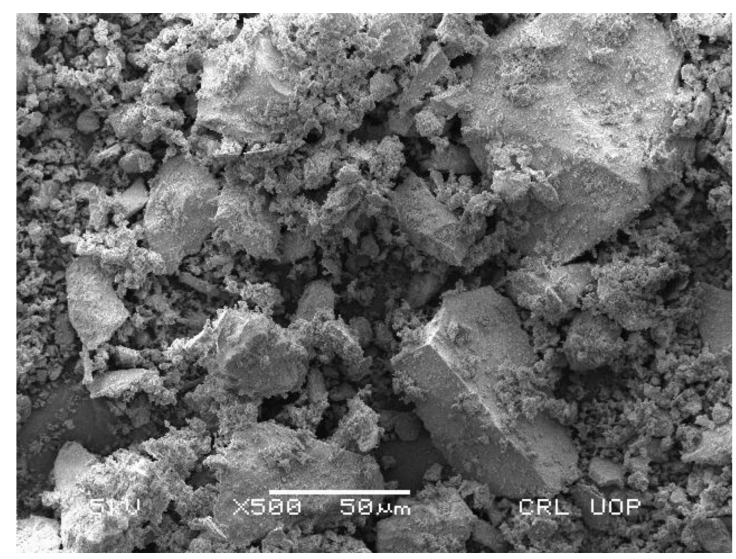

(c)

Figure 9. SEM Images of (a) WSA60, (b) WSA120, and (c) WSA240.

\subsubsection{Fratini Test (Grinding)}

The results of Fratini test are shown in Figure 10. It can be observed from this figure that WSA15 and WSA30 showed almost similar pozzolanic activity as that of non-ground ash. This is because very small increase in Blaine surface area was observed up to $30 \mathrm{~min}$ of grinding. WSA60 showed slightly better pozzolanic activity, accordingly to its increase in Blaine surface area. However, WSA120 and WSA240 showed better pozzolanic activity as compared to other ashes, as they are lying in the lowest region of the graph, indicating highest consumption of $\mathrm{CH}$. Nevertheless, the results show that the Fratini test did not differentiate the differences between distinct ashes. Similar behavior was reported by Cordeiro et al. [75], in which they ground rice husk samples for different durations ranging from 8 to $24 \mathrm{~min}$.

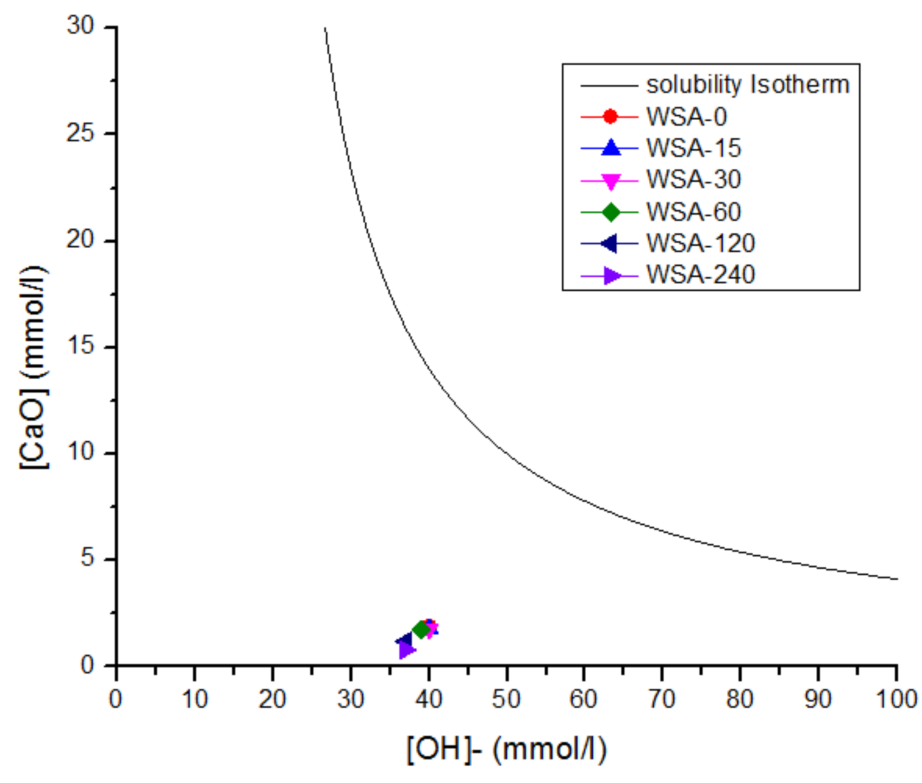

Figure 10. Solubility isotherm of Fratini Test at different grinding times.

\subsubsection{Chapelle Test (Grinding)}

The Chapelle test was conducted to observe the relation between Chapelle activity and grinding time. The results of Chapelle test are presented in Figure 11. The results show that Chapelle activity increases with grinding time. Up to $30 \mathrm{~min}$ of grinding, there is very small increase of $2.4 \%$ in 
Chapelle activity with respect to WSA0. Chapelle activity of WSA60 shows an increase of $6.4 \%$. Chapelle activity increases significantly after 120 and $240 \mathrm{~min}$ of grinding, due to significant increase in specific surface area, and an increase of $16.0 \%$ and $20.5 \%$ is observed. Similar behavior was observed by Cordeiro et al. [75], in which they showed that Chapelle activity increased with the increase in grinding time of rice husk ash. Figure 12 shows a direct relation between Blaine fineness and Chapelle activity, i.e., increase in Blaine fineness results in increased Chapelle activity, hence proving that increased surface area has improved the pozzolanic properties of the ashes.

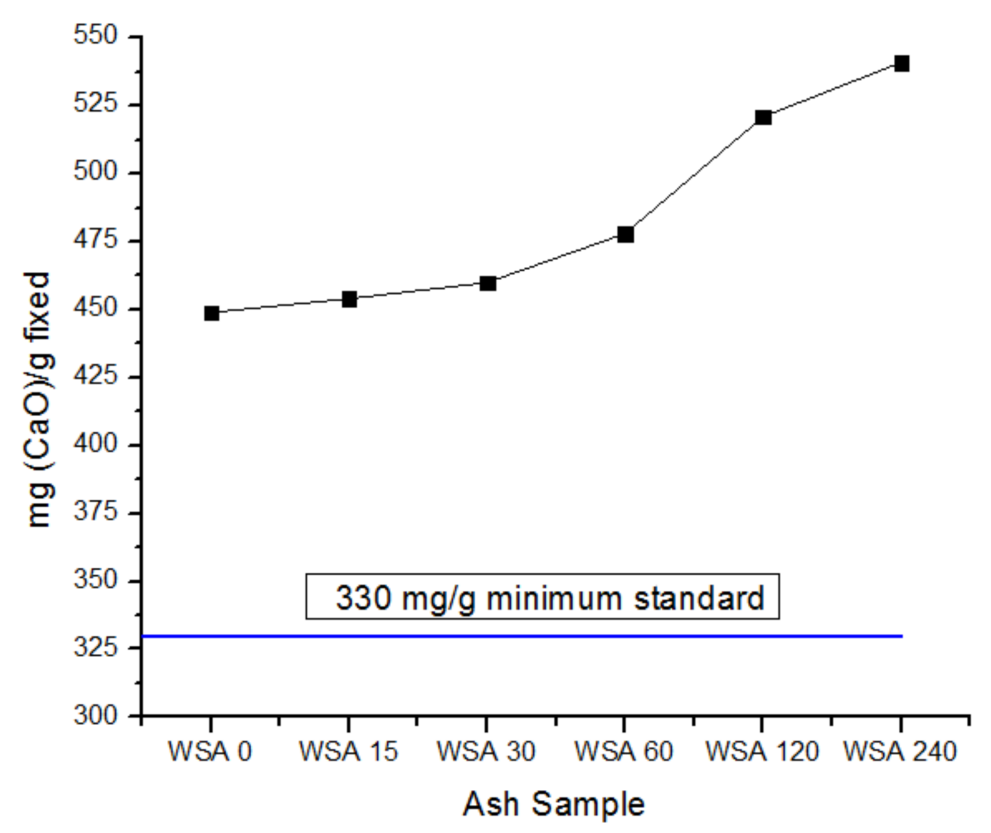

Figure 11. Relation between grinding durations and Chapelle activity for WSA sample calcined at $600{ }^{\circ} \mathrm{C}$.

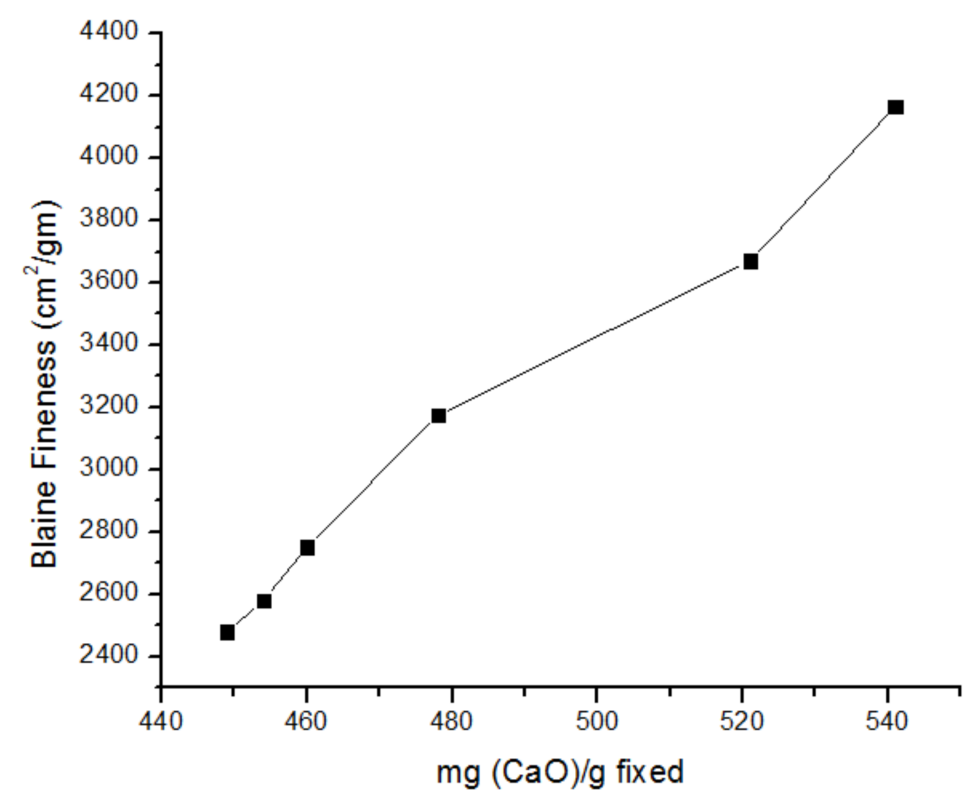

Figure 12. Relation between Chapelle activity and Blaine fineness for WSA sample calcined at $600{ }^{\circ} \mathrm{C}$.

\subsubsection{Pozzolanic Activity Index (Grinding)}

Pozzolanic Activity Index was calculated for ground WSA to check the strength contributions due to the enhanced surface area of the ground ashes. The results of PAI when WSA was used as $20 \%$ 
replacement of cement are presented in Table 5. It can be observed that only WSA120 and WSA240 fulfill the ASTM standard at 7 days with PAI of $78 \%$ and $77 \%$, respectively. Thus, to achieve minimum requirement $(75 \% \mathrm{PAI})$, the raw WSA needs to be ground for $120 \mathrm{~min}$. The compressive strength of WSA120 almost reached the strength of control sample, with a PAI of $98.72 \%$, while WSA240 showed highest PAI of $107.69 \%$ at 28 days, thus pointing to the fact that greater specific surface area enhances the pozzolanic properties of a material. WSA30 showed 7 and 28 days PAI of $66 \%$ and $85.25 \%$, respectively, while WSA60 showed slightly better PAI of $72.4 \%$ at 7 days and $91 \%$ at 28 days. In case of WSA0 and WSA15, the PAI value was found to be lower because of low values of specific surface area. The lowest PAI of wheat straw ash without grinding is due to the dilution effect [77]. Cordeiro et al. [78] evaluated the influence of particle size and specific surface area of rice husk ash on the PAI and found that PAI increased with the increase in fineness of RHA. In another research by Kiattikomol et al. [79], the authors found that fineness has significant influence on PAI. The results of WSA120 and WSA240 are also in line with those of Blaine fineness, which showed significant increase in surface area ( $48 \%$ and $68 \%$ ) after grinding for 120 and $240 \mathrm{~min}$.

Table 5. PAI of WSA blended cement cubes.

\begin{tabular}{ccccc}
\hline & $\begin{array}{c}\text { 7 Days Strength } \\
\text { (MPa) }\end{array}$ & $\begin{array}{c}\text { 7 Days Pozzolanic Activity Index } \\
\mathbf{( \% )}\end{array}$ & $\begin{array}{c}\text { 28 Days Strength } \\
\text { (MPa) }\end{array}$ & $\begin{array}{c}\text { 28 Days Pozzolanic Activity Index } \\
\mathbf{( \% )}\end{array}$ \\
\hline Control & 10.9 & 100 & 15.6 & 100 \\
WSA0 & 5.1 & 46.8 & 9.7 & 62.2 \\
WSA15 & 6.9 & 63.3 & 10.8 & 69.2 \\
WSA30 & 7.2 & 66 & 13.3 & 85.26 \\
WSA60 & 7.9 & 72.4 & 14.2 & 91.03 \\
WSA120 & 8.3 & 76.1 & 15.4 & 98.72 \\
WSA240 & 8.4 & 77.0 & 16.8 & 107.69 \\
\hline
\end{tabular}

\section{Conclusions}

Open burning of biomass, a predominant practice in many agricultural countries, leads to air pollution, smog, and health hazards. Particulate matter, especially that of a size less than $2.5 \mathrm{~mm}$ (PM 2.5), can reduce visibility into the atmosphere and deteriorate air quality, even away from the source of the burning. This research proposed an environmentally friendly method with which to dispose of wheat straw, i.e., the burning of wheat straw in a controlled environment, using the resulting ash in cement-based composites. It was primarily focused on finding the optimum condition of burning, which would result in the production of the best quality WSA to be used in cement-based composites. Different WSA samples were prepared at temperatures of $500^{\circ} \mathrm{C}, 600^{\circ} \mathrm{C}, 700{ }^{\circ} \mathrm{C}$, and $800{ }^{\circ} \mathrm{C}$ to find the optimum temperature at which WSA should be prepared with best pozzolanic properties. Based on XRF, XRD, Chapelle, Fratini, and PAI tests, the following conclusions can be drawn.

- XRD pattern showed that silica was mostly in amorphous phase in WSA500 and WSA600, but in the case of WSA500 a high organic content was found, as revealed by its low weight loss (75.1\%) and the dark color of its ash. With an increase in temperature (beyond $500{ }^{\circ} \mathrm{C}$ ), the weight loss increased, and the ash samples displayed a brighter color. However, amorphous silica transformed into crystalline silica, as is evident from the XRD results.

- Chemical tests revealed that, except for WSA800, all samples fulfilled the minimum requirements of the Chapelle and Fratini tests, but mechanically only one sample WSA600 fulfilled the ASTM requirement of minimum $75 \%$ PAI at 28 days. Due to the presence of crystalline phases of silica in WSA700 and WSA800, pozzolanic reaction was not efficient enough and thus resulted in low PAI. WSA600 showed highest Chapelle activity of $453.51 \mathrm{mg} / \mathrm{g}$ and had PAI of $85.2 \%$ at 28 days. Moreover, WSA600 showed highest silica content, and consequently highest quantity of $\left(\mathrm{SiO}_{2}+\mathrm{Al}_{2} \mathrm{O}_{3}+\mathrm{Fe}_{2} \mathrm{O}_{3}=80.16 \%\right)$. Hence, it can be concluded that $600{ }^{\circ} \mathrm{C}$ is the optimum calcination temperature. The resulting ash obtained at this temperature, for which agricultural 
waste such as bagasse is usually burnt at round $550{ }^{\circ} \mathrm{C}$ in cogeneration boiler to utilize its maximum fuel value, can become a value-added product for industry.

- After determining the optimum temperature, the WSA600 was ground for different durations $(15,30,60,120$, and $240 \mathrm{~min})$ to evaluate the effect of fineness and specific surface area upon their pozzolanic activity. The ground ashes were evaluated based on Blaine fineness, Chapelle, Fratini, SEM, and PAI tests.

- From the Blaine fineness test, it was observed that up to 30 min of grinding, there was an insignificant increase in Blaine surface area of just $11 \%$ with respect to WSA before grinding, while an increase of $28 \%, 48 \%$, and $68 \%$ was observed in Blaine surface area after $60 \mathrm{~min}, 120 \mathrm{~min}$, and 240 min of grinding, respectively.

- The results of chemical tests showed that Chapelle activity increases with grinding time. WSA15 and WSA30 showed almost similar Chapelle activity to that of non-ground ashes. Chapelle activity increased significantly after 120 and $240 \mathrm{~min}$ of grinding, due to a significant increase in specific surface area; additionally, an increase of $16.0 \%$ and $20.5 \%$ was observed.

- From the PAI results, it was observed that only WSA120 and WSA240 fulfilled the ASTM requirement of $75 \%$ PAI at both 7 and 28 days, thus pointing to the fact that greater specific surface area enhances the pozzolanic properties of a material. It was also observed that grinding had a direct relation to the Blaine surface area of the ashes, and consequently its PAI. However, as grinding is an energy-intensive process, so grinding WSA for $120 \mathrm{~min}$ is adequate for its pozzolanic performance. Also, the SEM images of ground ashes showed breaking of coarser particles into finer particles with grinding due to the mechanical action of the grinding media, since the particle size distribution has an influence on the pozzolanic performance of cement-based composites. It is therefore suggested that, in future research, its role should be investigated. Furthermore, the role of the speed of the ball mill should be investigated.

Conclusively, wheat straw after calcining at $600{ }^{\circ} \mathrm{C}$ and then grinding for $120 \mathrm{~min}$ was found to be the most effective method. Hence, it can be concluded that WSA is a feasible pozzolanic material and could be partially replaced with a percentage of cement without any negative effect upon its properties. The addition of WSA in cement-based composites would achieve manifold objectives, i.e., the use of wheat straw as fuel for electricity production, aiding in the production of an environmentally friendly concrete; the sustainable use of raw material expended during cement production; and the adding of economic value to wheat straw, creating an incentive to the farmer to refrain from the open burning of wheat straw.

Acknowledgments: This research was supported by Nazarbayev University Faculty development competitive research grants (090118FD5316).

Author Contributions: S.A.M. and I.W. conceived and designed the experiments; I.W. and M.K.K. performed the experiments; S.A.M., M.A.T., and M.B. analyzed the data; M.A.T. and M.K.K. reagents/materials/analysis tools; S.A.M. and I.W. wrote the paper.

Conflicts of Interest: The authors declare no conflict of interest.

\section{References}

1. Zhang, H.; Wang, S.; Hao, J.; Wang, X.; Wang, S.; Chai, F.; Li, M. Air pollution and control action in Beijing. J. Clean. Prod. 2016, 112, 1519-1527. [CrossRef]

2. Zhao, H.; Zhang, X.; Zhang, S.; Chen, W.; Tong, D.; Xiu, A. Effects of Agricultural Biomass Burning on Regional Haze in China: A Review. Atmosphere 2017, 8, 88. [CrossRef]

3. Gao, R.; Jiang, W.; Gao, W.; Sun, S. Emission inventory of crop residue open burning and its high-resolution spatial distribution in 2014 for Shandong province, China. Atmos. Pollut. Res. 2017, 8, 545-554. [CrossRef]

4. Yan, X.; Ohara, T.; Akimoto, H. Bottom-up estimate of biomass burning in mainland China. Atmos. Environ. 2006, 40, 5262-5273. [CrossRef] 
5. Van der Werf, G.R.; Randerson, J.T.; Giglio, L.; Collatz, G.J.; Mu, M.; Kasibhatla, P.S.; Morton, D.C.; DeFries, R.S.; Jin, Y.; van Leeuwen, T.T. Global fire emissions and the contribution of deforestation, savanna, forest, agricultural, and peat fires (1997-2009). Atmos. Chem. Phys. 2010, 10, 11707-11735. [CrossRef]

6. Zhang, X.; Ma, F. Emergy Evaluation of Different Straw Reuse Technologies in Northeast China. Sustainability 2015, 7, 11360-11377. [CrossRef]

7. Zhuang, Y.; Li, R.; Yang, H.; Chen, D.; Chen, Z.; Gao, B.; He, B. Understanding Temporal and Spatial Distribution of Crop Residue Burning in China from 2003 to 2017 Using MODIS Data. Remote Sens. 2018, 10, 390. [CrossRef]

8. Gadde, B.; Bonnet, S.; Menke, C.; Garivait, S. Air pollutant emissions from rice straw open field burning in India, Thailand and the Philippines. Environ. Pollut. 2009, 157, 1554-1558. [CrossRef] [PubMed]

9. Streets, D.G.; Yarber, K.F.; Woo, J.H.; Carmichael, G.R. Biomass burning in Asia: Annual and seasonal estimates and atmospheric emissions. Glob. Biogeochem. Cycles 2003, 17. [CrossRef]

10. Zhang, H.; Hu, J.; Qi, Y.; Li, C.; Chen, J.; Wang, X.; He, J.; Wang, S.; Hao, J.; Zhang, L.; et al. Emission characterization, environmental impact, and control measure of PM2.5 emitted from agricultural crop residue burning in China. J. Clean. Prod. 2017, 149, 629-635. [CrossRef]

11. Crounse, J.D.; DeCarlo, P.F.; Blake, D.R.; Emmons, L.K.; Campos, T.L.; Apel, E.C.; Clarke, A.D.; Weinheimer, A.J.; McCabe, D.C.; Yokelson, R.J.; et al. Biomass burning and urban air pollution over the Central Mexican Plateau. Atmos. Chem. Phys. 2009, 9, 4929-4944. [CrossRef]

12. Chen, G.; Guan, Y.; Tong, L.; Yan, B.; Hou, L. Spatial estimation of PM2.5 emissions from straw open burning in Tianjin from 2001 to 2012. Atmos. Environ. 2015, 122, 705-712. [CrossRef]

13. NASA. NASA Worldview. Available online: https://worldview.earthdata.nasa.gov/?p=geographic\& l=MODIS_Aqua_CorrectedReflectance_TrueColor(hidden),MODIS_Terra_CorrectedReflectance_ TrueColor(hidden),VIIRS_SNPP_CorrectedReflectance_TrueColor,Reference_Features(hidden), Reference_ Labels,Coastlines,VIIRS_SNPP_Fires_375m_Night(hidden),VIIRS_SNPP_Fires_375m_Day\&t=2016-11$01 \& z=3 \& v=65.36657008891676,23.68144953111502,86.95250758891676,37.79668390611502 \& a b=o f f \& a s=$ 2016-10-18\&ae=2016-10-27\&av=3\&al=true (accessed on 15 January 2018).

14. Wikimedia. Wikimedia Commons; Wikimedia: San Francisco, CA, USA, 2016.

15. FAO World Food Situation. Available online: http://www.fao.org/worldfoodsituation/csdb/en/ (accessed on 17 September 2016).

16. Pan, X.; Sano, Y. Fractionation of wheat straw by atmospheric acetic acid process. Bioresour. Technol. 2005, 96, 1256-1263. [CrossRef] [PubMed]

17. Singh, Y. Bijay, Efficient management of primary nutrients in the rice-wheat system. J. Crop Prod. 2001, 4, $23-85$. [CrossRef]

18. Gadde, B.; Menke, C.; Wassmann, R. Rice straw as a renewable energy source in India, Thailand, and the Philippines: Overall potential and limitations for energy contribution and greenhouse gas mitigation. Biomass Bioenergy 2009, 33, 1532-1546. [CrossRef]

19. Kadam, K.L.; Forrest, L.H.; Jacobson, W.A. Rice straw as a lignocellulosic resource: Collection, processing, transportation, and environmental aspects. Biomass Bioenergy 2000, 18, 369-389. [CrossRef]

20. Kausar, H.; Sariah, M.; Saud, H.M.; Alam, M.Z.; Ismail, M.R. Development of compatible lignocellulolytic fungal consortium for rapid composting of rice straw. Int. Biodeterior. Biodegrad. 2010, 64, 594-600. [CrossRef]

21. John, A. Alternatives to Open-Field Burning on Paddy Farms; Agricultural and Food Policy Studies Institute: Serdang, Malaysia, 2013; Volume 18.

22. Bank, W. Decision Makers' Guide to Municipal Solid Waste Incineration. Available online: http:/ / web.mit. edu/urbanupgrading/urbanenvironment/resources/references/pdfs/DecisionMakers.pdf (accessed on 8 April 2017).

23. Lam, C.H.K.; Ip, A.W.M.; Barford, J.P.; McKay, G. Use of Incineration MSW Ash: A Review. Sustainability 2010, 2, 1943-1968. [CrossRef]

24. Eriksson, O.; Carlsson Reich, M.; Frostell, B.; Björklund, A.; Assefa, G.; Sundqvist, J.O.; Granath, J.; Baky, A.; Thyselius, L. Municipal solid waste management from a systems perspective. J. Clean. Prod. 2005, 13, $241-252$. [CrossRef]

25. Yang, Y.; Sharifi, V.; Swithenbank, J. Effect of air flow rate and fuel moisture on the burning behaviours of biomass and simulated municipal solid wastes in packed beds. Fuel 2004, 83, 1553-1562. [CrossRef]

26. Akram, T.; Memon, S.A.; Obaid, H. Production of low cost self compacting concrete using bagasse ash. Constr. Build. Mater. 2009, 23, 703-712. [CrossRef] 
27. Neville, A.M. Properties of Concrete; Pearson Education Asia Pte. Ltd.: London, UK, 2000; pp. 7, 25, 31-35, 62, 63,83 and 86.

28. Hendrik, G.v.O.; Padovani, A.C. Cement Manufacture and the Environment Part II: Environmental Challenges and Opportunities. J. Ind. Ecol. 2003, 7, 93-126.

29. Malhotra, V.M. Role of Supplementary Cementing Materials in Reducing Greenhouse Gas Emissions; Sheffield Academic Press: Sheffield, UK, 1999.

30. Pacheco-Torgal, F.; Castro-Gomes, J.; Jalali, S. Alkali-activated binders: A review: Part 1. Historical background, terminology, reaction mechanisms and hydration products. Constr. Build. Mater. 2008, 22, 1305-1314. [CrossRef]

31. Kim, T.; Tae, S.; Chae, C.; Lee, K. Proposal for the Evaluation of Eco-Efficient Concrete. Sustainability 2016, 8, 705. [CrossRef]

32. Kim, T. Assessment of Construction Cost Saving by Concrete Mixing the Activator Material. Sustainability 2016, 8, 403. [CrossRef]

33. Paris, J.M.; Roessler, J.G.; Ferraro, C.C.; DeFord, H.D.; Townsend, T.G. A review of waste products utilized as supplements to Portland cement in concrete. J. Clean. Prod. 2016, 121, 1-18. [CrossRef]

34. Mo, K.H.; Alengaram, U.J.; Jumaat, M.Z.; Yap, S.P.; Lee, S.C. Green concrete partially comprised of farming waste residues: A review. J. Clean. Prod. 2016, 117, 122-138. [CrossRef]

35. Ortega, J.; Tremiño, R.; Sánchez, I.; Climent, M. Effects of Environment in the Microstructure and Properties of Sustainable Mortars with Fly Ash and Slag after a 5-Year Exposure Period. Sustainability 2018, 10, 663. [CrossRef]

36. Alnahhal, M.; Alengaram, U.; Jumaat, M.; Alqedra, M.; Mo, K.; Sumesh, M. Evaluation of Industrial By-Products as Sustainable Pozzolanic Materials in Recycled Aggregate Concrete. Sustainability 2017, 9, 767. [CrossRef]

37. Memon, S.A.; Khan, M.K. Ash blended cement composites: Eco-friendly and sustainable option for utilization of corncob ash. J. Clean. Prod. 2018, 175, 442-455. [CrossRef]

38. Memon, S.A.; Shaikh, M.A.; Akbar, H. Utilization of Rice Husk Ash as viscosity modifying agent in Self Compacting Concrete. Constr. Build. Mater. 2011, 25, 1044-1048. [CrossRef]

39. Eisentraut, A. Sustainable Production of Second-Generation Biofuels, Potential and Perspectives in Major Economies and Developing Countries; IEA: Paris, France, 2010.

40. Duku, M.H.; Gu, S.; Hagan, E.B. A comprehensive review of biomass resources and biofuels potential in Ghana. Renew. Sustain. Energy Rev. 2011, 15, 404-415. [CrossRef]

41. Mohammed, Y.S.; Mokhtar, A.S.; Bashir, N.; Saidur, R. An overview of agricultural biomass for decentralized rural energy in Ghana. Renew. Sustain. Energy Rev. 2013, 20, 15-25. [CrossRef]

42. Pode, R. Potential applications of rice husk ash waste from rice husk biomass power plant. Renew. Sustain. Energy Rev. 2016, 53, 1468-1485. [CrossRef]

43. Xu, W.; Lo, T.Y.; Memon, S.A. Microstructure and reactivity of rich husk ash. Constr. Build. Mater. 2012, 29, 541-547. [CrossRef]

44. Ryou, J. Examination of grinding techniques for the reuse of by-products of cement production. Mater. Lett. 2004, 58, 425-427. [CrossRef]

45. Chandrasekhar, S.; Pramada, P.N.; Majeed, J. Effect of calcination temperature and heating rate on the optical properties and reactivity of rice husk ash. J. Mater. Sci. 2006, 41, 7926-7933. [CrossRef]

46. ASTM International. Standard Test Methods for Sampling and Testing Fly Ash or Natural Pozzolans for Use in Portland-Cement Concrete; ASTMC311M-13; ASTM Internationals: West Conshohocken, PA, USA, 2013.

47. British Standards Institution. Method of Testing Cement. Pozzolanicity Test for Pozzolanic Cement; BS-EN196-2005; British Standards Institution: London, UK, 2005.

48. Raverdy, M.; Brivot, F.; Paillère, A.M.; Bron, R. Appréciation de l'activité pouzzolanique de constituents secondaires. In Proceedings of the 7e Congrés International de la Chimie des Ciments, Paris, France, 30 June-4 July 1980; pp. 6-41.

49. ASTM. Standard Test Method for Fineness of Hydraulic Cement by Air-Permeability Apparatus; ASTM Internationals: West Conshohocken, PA, USA, 2000.

50. Zain, M.F.M.; Islam, M.N.; Mahmud, F.; Jamil, M. Production of rice husk ash for use in concrete as a supplementary cementitious material. Constr. Build. Mater. 2011, 25, 798-805. [CrossRef] 
51. Valipour, M.; Pargar, F.; Shekarchi, M.; Khani, S. Comparing a natural pozzolan, zeolite, to metakaolin and silica fume in terms of their effect on the durability characteristics of concrete: A laboratory study. Constr. Build. Mater. 2013, 41, 879-888. [CrossRef]

52. Adesanya, D.; Raheem, A. Development of corn cob ash blended cement. Constr. Build. Mater. 2009, 23, 347-352. [CrossRef]

53. Cordeiro, G.; Toledo Filho, R.; Fairbairn, E. Effect of calcination temperature on the pozzolanic activity of sugar cane bagasse ash. Constr. Build. Mater. 2009, 23, 3301-3303. [CrossRef]

54. Kizhakkumodom Venkatanarayanan, H.; Rangaraju, P.R. Effect of grinding of low-carbon rice husk ash on the microstructure and performance properties of blended cement concrete. Cem. Concr. Compos. 2015, 55, 348-363. [CrossRef]

55. Nehdi, M.; Duquette, J.; El Damatty, A. Performance of rice husk ash produced using a new technology as a mineral admixture in concrete. Cem. Concr. Res. 2003, 33, 1203-1210. [CrossRef]

56. Coloring Oxides Basic Percentages. Available online: http:/ / ceramicartsdaily.org/wp-content/uploads / 2013/05/Coloring-Oxides-Basic-Percentages.pdf (accessed on 17 September 2017).

57. Peterson, S.; Peterson, J. The Craft and Art of Clay: A Complete Potter's Handbook; Laurence King Publishing: London, UK, 2003.

58. Rydholm, S.A. Pulping Processes; Interscience Publishers: Geneva, Switzerland, 1965; pp. 1049-1053.

59. Khushnood, R.A.; Rizwan, S.A.; Memon, S.A.; Tulliani, J.-M.; Ferro, G.A. Experimental Investigation on Use of Wheat Straw Ash and Bentonite in Self-Compacting Cementitious System. Adv. Mater. Sci. Eng. 2014, 2014, 832508. [CrossRef]

60. Atchison, J.E. Present Status and Future Potential for Utilization of Nonwood Plant Fibres-A Worldwide Review; Indian Pulp \& Paper Pvt. Ltd.: West Bengal, India, 1974.

61. ASTM International. Standard Specification for Coal Fly Ash and Raw or Calcined Natural Pozzolan for Use in Concrete; ASTMC618-15; ASTM International: West Conshohocken, PA, USA, 2015.

62. Malhotra, V.M.; Mehta, P.K. Pozzolanic and Cementitious Materials; Taylor \& Francis: Didcot, UK, 1996 ; Volume 1.

63. Ramachandran, V.S.; Paroli, R.M.; Beaudoin, J.J.; Delgado, A.H. Handbook of Thermal Analysis of Construction Materials; William Andrew: New York, NY, USA, 2002.

64. Krishnarao, R.V.; Subrahmanyam, J.; Jagadish Kumar, T. Studies on the formation of black particles in rice husk silica ash. J. Eur. Ceram. Soc. 2001, 21, 99-104. [CrossRef]

65. Biricik, H.; Aköz, F.; Berktay, I.L.; Tulgar, A.N. Study of pozzolanic properties of wheat straw ash. Cem. Concr. Res. 1999, 29, 637-643. [CrossRef]

66. Patel, M.; Karera, A.; Prasanna, P. Effect of thermal and chemical treatments on carbon and silica contents in rice husk. J. Mater. Sci. 1987, 22, 2457-2464. [CrossRef]

67. Bahurudeen, A.; Santhanam, M. Influence of different processing methods on the pozzolanic performance of sugarcane bagasse ash. Cem. Concr. Compos. 2015, 56, 32-45. [CrossRef]

68. Bell, F.G. Foundation Engineering in Difficult Ground; Elsevier: New York, NY, USA, 2013.

69. Young, J. Reaction Mechanism of Organic Admixtures with Hydrating Cement Compounds. Transp. Res. Rec. 1976, 564.

70. Corapcioglu, M.Y. Advances in Porous Media; Elsevier: New York, NY, USA, 1996; Volume 3.

71. Cordeiro, G.; Toledo Filho, R.; Tavares, L.; Fairbairn, E. Pozzolanic activity and filler effect of sugar cane bagasse ash in Portland cement and lime mortars. Cem. Concr. Compos. 2008, 30, 410-418. [CrossRef]

72. Karim, M.R.; Hossain, M.M.; Khan, M.N.N.; Zain, M.F.M.; Jamil, M.; Lai, F.C. On the utilization of pozzolanic wastes as an alternative resource of cement. Materials 2014, 7, 7809-7827. [CrossRef] [PubMed]

73. Cordeiro, G.C.; Toledo Filho, R.D.; Tavares, L.M.; Fairbairn, E.d.M.R. Ultrafine grinding of sugar cane bagasse ash for application as pozzolanic admixture in concrete. Cem. Concr. Res. 2009, 39, 110-115. [CrossRef]

74. Isaia, G.C.; Gastaldini, A.L.G.; Moraes, R. Physical and pozzolanic action of mineral additions on the mechanical strength of high-performance concrete. Cem. Concr. Compos. 2003, 25, 69-76. [CrossRef]

75. Cordeiro, G.C.; Toledo Filho, R.D.; de Moraes Rego Fairbairn, E. Use of ultrafine rice husk ash with high-carbon content as pozzolan in high performance concrete. Mater. Struct. 2009, 42, 983-992. [CrossRef]

76. Xu, W.; Lo, Y.T.; Ouyang, D.; Memon, S.A.; Xing, F.; Wang, W.; Yuan, X. Effect of rice husk ash fineness on porosity and hydration reaction of blended cement paste. Constr. Build. Mater. 2015, 89, 90-101. [CrossRef]

77. Lawrence, P.; Cyr, M.; Ringot, E. Mineral admixtures in mortars: Effect of inert materials on short-term hydration. Cem. Concr. Res. 2003, 33, 1939-1947. [CrossRef] 
78. Cordeiro, G.C.; Toledo Filho, R.D.; Tavares, L.M.; Fairbairn, E.d.M.R.; Hempel, S. Influence of particle size and specific surface area on the pozzolanic activity of residual rice husk ash. Cem. Concr. Compos. 2011, 33, 529-534. [CrossRef]

79. Kiattikomol, K.; Jaturapitakkul, C.; Songpiriyakij, S.; Chutubtim, S. A study of ground coarse fly ashes with different finenesses from various sources as pozzolanic materials. Cem. Concr. Compos. 2001, 23, 335-343. [CrossRef]

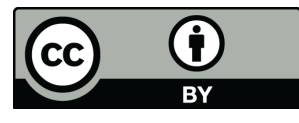

(C) 2018 by the authors. Licensee MDPI, Basel, Switzerland. This article is an open access article distributed under the terms and conditions of the Creative Commons Attribution (CC BY) license (http://creativecommons.org/licenses/by/4.0/). 